\title{
Rosacea: Not Curse of the Celts, But of Many More
}

\author{
Christian Diehl* \\ Department of Dermatology, University Marconi, Italy \\ *Corresponding author: Christian Diehl, Professor of Dermatology, University Marconi, Via Vittoria Colonna 11, Rome, Italy. \\ To Cite This Article: Christian Diehl. Rosacea: Not Curse of the Celts, But of Many More. Am J Biomed Sci \& Res. 2019 - 4(4). AJBSR.MS.ID.000817. \\ DOI: 10.34297/AJBSR.2019.04.000817
}

Received: August 02, 2019 | Published: August 12, 2019

\section{Introduction}

From what I can remember from my medical studies, a long time ago, when our Professors were naming rosacea as "acne-rosacea", there was always a mention to its nickname: the "Curse of the Celts". Hence our formation was including the notion that rosacea was more common among the fair-haired, blue-eyed "Nordic type" [1]. Meanwhile, over the years and with more experience and a deeper knowledge of other continents and populations, I was able to observe that this notion was not exactly and even far from being correct.

About the epidemiology of rosacea, during a long time there was no reliable data, and when a paper was mentioning it, it was most often with sporadic and hazardous numbers. To date, this situation improved, and various general population surveys bring more precise numbers, ranging between less than $1 \%$ to more than $20 \%$, but direct comparison between studies can be biased by differences in methodology, populations, and cultural and social perceptions of disease [2]. For sure, general population prevalence is optimally determined by surveying the entire population using specific case finding criteria with evaluations performed by trained observers [3]. Among such surveys, the earliest one was performed in 1948 and involved almost 11,000 residents of the Faroe Islands (almost one third of the total population at that time) and the prevalence of rosacea was $0.09 \%$ [4]. Further, in 1989 in Sweden, in a non-selected population of more than 800 office employees, the prevalence was $10 \%$ [5]. Large retrospective US database have compiled prevalence rates of $1,3 \%$ to $2,1 \%$ [6,7]. In Germany, surveys on 49,000 and 90,800 workers gave prevalence rates of $2.2 \%$ and $2.3 \%[8,9]$. In Estonia, the rate found in a cohort of 348 was surprisingly high at $22 \%$ [10] whilst in Ireland, in a mix of 1,000 office and outdoor workers it was $2.7 \%$ [11]. In an observational study on more than 120,000 subjects conducted in UK, the overall incidence rate for diagnosed rosacea was established at 1.65 per 1000 person-years [12].

As we can see, most of surveys of prevalence of rosacea were performed in North-European countries or in the USA. However, we can also find reports from other countries, where exclusive phototype is not Fitzpatrick I or II, but rather III or IV. In Santander (Spain) among 395 patients consulting in a primary healthcare centre for non-dermatological reasons, the prevalence of rosacea was 5.5\% [13]. In Lima (Peru), in an evaluation of the frequency of dermatological diseases at University Department of Dermatology, prevalence of rosacea was scored as $1.97 \%$ [14]. Among 6,822 patients who presented to the consultation at the Dermatology Department (Hôtel-Dieu de France University Hospital) in Beirut (Lebanon) the prevalence rate of rosacea was around 2\% [15]. In India, rosacea was referred as not being as uncommon as in other Asian countries, and accounting for about $0.5 \%$ of dermatological consultations [16]. As per black patients, rosacea is less common but not rare in patients with skin of colour [17].

A rapid analysis of the results previously reported leads to amazing results. Whilst the prevalence of rosacea appears quite homogenous in the surveys performed in North-Europe and the USA, surrounding 2\%, with the exceptions of the Faroese and Estonian reports, the prevalence in countries with higher phototypes such as Peru or Lebanon is displaying similar values. Hence, we must reconsider this nickname that we are giving to rosacea of "Curse of the Celts". Irish and British are the very definition of Celts, and the prevalence of rosacea was not shown to be higher among them than in some other ethnic groups. Let's not behave as did likely my late grandmother, who read once an information and repeated it at will without controlling the basis of the same. Even if the symptoms of rosacea are not as visible in higher phototypes than in fair-skinned individuals and don't feature the characteristic red-face pattern, we must consider this disorder in our differential diagnosis when dark-skinned patients present with facial flushing, warmth, ocular symptoms or acne-like eruptions lacking comedones.

\section{References}

1. Marks R, Wilkinson DS (1986) Rosacea In: Rook AJ, et al (Eds). Textbook of Dermatology, $4^{\text {th }}$ edn, Oxford: Blackwell Scientific Publications 2: 1605-1610. 
2. Chosidow 0, Cribier B (2011) Epidemiology of rosacea: updated data Ann Dermatol Venereol 138(Suppl 2): S124-128.

3. Tan J, Berg M (2013) Rosacea: current state of epidemiology. J Am Acad Dermatol 69(6 suppl 1): S27-S35.

4. Lomholt $\mathrm{G}$ (1964) Prevalence of skin diseases in a population: a census study from the Faroe Islands. Dan Med Bull 11: 1-7.

5. Berg M, Liden S (1989) An epidemiological study of rosacea. Acta Derm Venereol 69(5): 419-423.

6. Bamford JT, Gessert CE, Renier CM, Jackson MM, Laabs SB, et al. (2006) Childhood stye and adult rosacea. J Am Acad Dermatol 55(6): 951-955.

7. Romanowicz M, Stephenson JJ, Del Rosso JQ, Lenhart G (2008) Healthcare utilization and costs of patients with rosacea in an insured population. J Drugs Dermatol 7(1): 41-49.

8. Schaefer I, Rustenbach SJ, Zimmer L, Augustin M (2008) Prevalence of skin diseases in a cohort of 48,665 employees in Germany. Dermatology 217(2): 169-172.

9. Augustin M, Herberger K, Hintzen S, Heigel H, Franzke N, et al. (2011) Prevalence of skin lesions and need for treatment in a cohort of 90,880 workers. Br J Dermatol 165(4): 865-873.
10. Abram K, Silm H, Oona M (2010) Prevalence of rosacea in an Estonian working population using a standard classification. Acta Derm Venereol 90(3): 269-273.

11. McAleer MA, Fitzpatrick P, Powell FC (2010) Papulopustular rosacea: prevalence and relationship to photodamage. J Am Acad Dermatol 63(1): 33-39.

12. Spoendlin J, Voegel JJ, Jick SS, Meier CR (2012) A study on the epidemiology of rosacea in the U.K. Br J Dermatol 167(3): 598-605.

13. Ortiz A, Herrera T, Pérez del Molino C, Piñeiro F, Perales ML, et al. (1992) Epidemiology of Skin Diseases in Primary Health Care. Rev San Hig Púb 66: 71-82.

14. Gutierrez E, Chía H, Galarza C (2009) Skin diseases in a Dermatology Academic Teaching Division of Lima-Peru, 2004-2007. Dermatología Peruana 19(4): 308-315.

15. Tomb RR, Nassar IS (2000) Profile of skin diseases observed in a department of dermatology (1995-2000). J Med Liban 48(5): 302-309.

16. Wollina U, Verma SB (2009) Rosacea and Rhinophyma: not curse of the Celts but Indo-Eurasians. J Cosmet Dermatol 8(3): 234-235.

17. Alexis AF (2010) Rosacea in patients with skin of color: uncommon but not rare. Cutis 86(2): 60-62. 